\title{
Seasonal Variation in Interstitial Fluid Quality of the Andoni Flats, Niger Delta, Nigeria
}

\author{
${ }^{1 * A N S A, ~ E J ; ~}{ }^{2}$ SIKOKI, FD; ${ }^{2}$ FRANCIS, A $;{ }^{3}$ ALLISON, ME \\ ${ }^{1 *}$ African Regional Aquaculture Centre/Nigerian Institute for Oceanography and Marine Research, P.M.B. 5122, Port Harcourt, Nigeria. \\ ${ }^{2}$ Department of Animal and Environmental Biology, University of Port Harcourt, Port Harcourt, Nigeria \\ ${ }^{3}$ Department of Fisheries, Niger Delta University, Wilberforce Island, Bayelsa State, Nigeria.
}

\begin{abstract}
Physicochemical characteristics of the interstitial fluid of the sediment of the intertidal and subtidal zones of the Andoni flats were studied. The results for the interstitial fluid showed low dissolved oxygen levels $(0.1-$ $1.3 \mathrm{mg} / \mathrm{l})$, high temperature values $\left(26.2-32.4^{\circ} \mathrm{C}\right)$, wide salinity range $(8-21 \mathrm{ppt})$ and near neutral $\mathrm{pH}(6.26-7.76)$ across stations. Sampling duration was from January 1999 to December 2000 covering both wet season (April October) and dry season (November - March). The implications of the effects of fluctuating environmental variables on in-fauna inhabiting sediment are discussed. @JASEM
\end{abstract}

In recent times studies on the water quality of estuaries and coastal systems in Nigeria have received some level of increasing attention (Akpan and Offem, 1993; Akpan, 1999; Ajao and Fagade, 2002; Akpan et al, 2003; Ekeh and Sikoki, 2003; Francis 2003; Edokpayi et al, 2004); however these studies have been restricted to the surface and bottom water. Baseline data on the interstitial fluid quality of bottom sediment of tidal rivers and coastal zones are lacking. The interstitial fluid occupies the interstices between sediment/soil particles and provides a medium for habitation and survival of infauna organisms; especially for those infauna inhabiting intertidal areas that are exposed at low tide to atmospheric conditions due to diurnal tidal cycles. The absence of data on the interstitial fluid characteristics leaves a scientific gap with no option of a reference point in case of impact on the environment.

The present study is aimed at providing data on the basic physicochemical parameters of interstitial fluid of sediment in the intertidal zone of the Andoni flats. This is expected to serve as a point of reference in case of impact on the environment through human exploitation and exploration activities.

\section{MATERIALS AND METHODS}

Study Area: The study area is located in the Andoni flats and lies on latitude $4^{\circ} 34^{\prime} \mathrm{N}$ and longitude $7^{\circ} 22^{\prime}$ to $7^{\circ} 23^{\prime} \mathrm{E}$ (Fig. 1). It is a brackish water habitat traversed by the Ajakajak Creek which emanates from the Andoni River system. The area is characteristically bordered by vegetation comprising red mangrove Rhizophora sp and the nipa palm Nypa fruticans. Stations sampled were station I located on the same side of the Kaa fish market at the high water of neap tide in the intertidal zone. Station I was bare i.e. without vegetation and normally exposed at low tide to aerial conditions. Station II was fringed by mangrove vegetation (Rhizophora $\mathrm{sp}$ and Nypa fruticans) which provided shade over the sediment and was in the intertidal zone. Station III was situated at the low water of neap tide in the intertidal zone it was also bare and exposed to aerial conditions at low tide. Station IV was located in the subtidal zone along the Ajakajak Creek which implied that this station was always submerged.

Interstitial Fluid: Bimonthly samples of the physicochemical parameters of the sediment interstitial fluid namely salinity, dissolved oxygen, $\mathrm{pH}$ and temperature were measured in each station from January 1999 to December 2000. Data have been pooled and are presented as means based on the two seasons: a) rainy season spanning from April to October and b) dry season which stretches from November to March. Salinity was measured with the aid of a NEW-S 100 refractometer, dissolved oxygen was measured in situ using an OxyGuard Handy Mk II digital meter, $\mathrm{pH}$ and temperature were measured in situ with HANNA equipment model HT8915 ATC digital meter. Measurements were taken at low tide. A hand trowel was used to dig a narrow hole $(10 \mathrm{~cm}$ deep $X 10 \mathrm{~cm}$ wide) in the sediment to allow for seepage and collection of interstitial fluid in the hole. After five minutes, the fluid in the hole was tested with the meters and values recorded. The interstitial fluid for station IV was measured by obtaining sediment with the aid of a Hydrobios grab $\left(0.022 \mathrm{~m}^{2}\right)$; following this the procedure outlined above was used to estimate the parameters. 


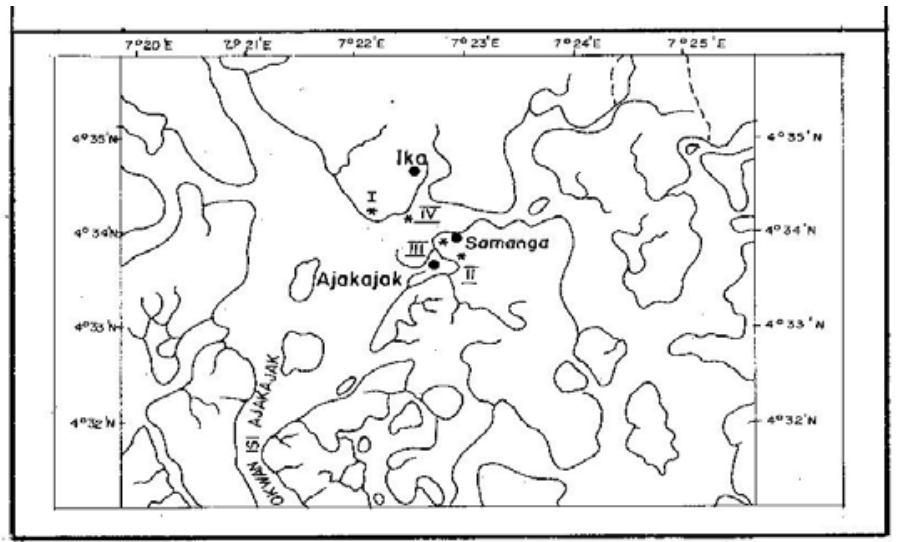

Fig. 1 : Map of study Area

\section{RESULTS}

Physicochemistry of Interstitial Fluid:

Temperature: Monthly temperature values varied from $26.2^{\circ} \mathrm{C}$ to $32.4^{\circ} \mathrm{C}$ across stations; with stations I and III recording higher monthly means than stations II and IV respectively (Fig. 2). ANOVA values showed statistically significant temporal differences in temperature, $\mathrm{p}<0.05$ (Table 1). Although statistically significant monthly variations were observed for temperature across stations, ANOVA values indicated that these differences did not vary significantly on a seasonal basis, $\mathrm{p}>0.05$ (Table 2).

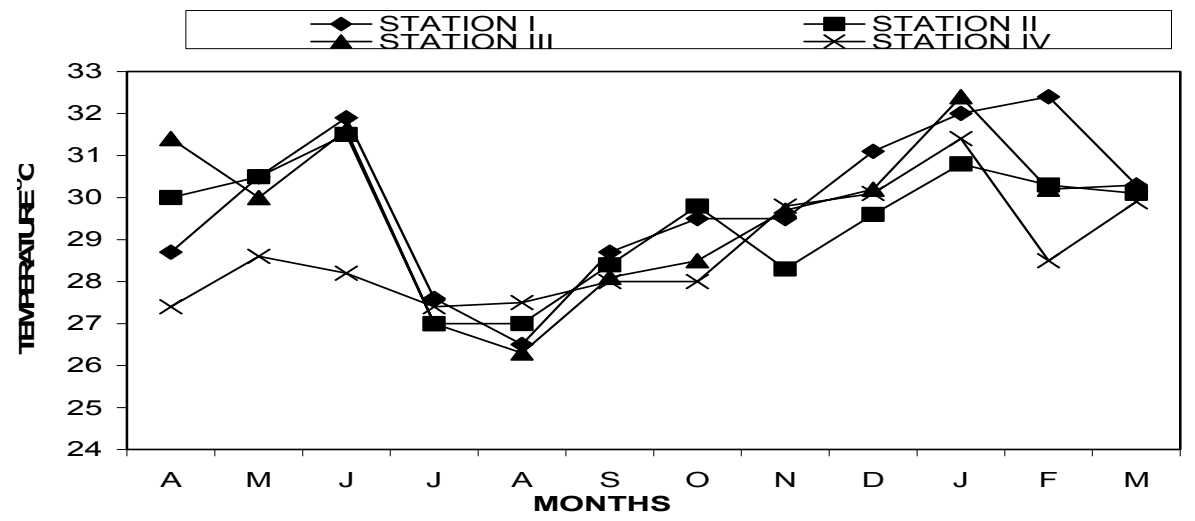

FIG. 2: MEAN MONTHLY VARIATION OF TEMPERATURE ${ }^{\circ} \mathrm{C}$ OF INTERSTITIAL FLUID IN THE ANDONI FLATS

Table 1: Temporal Variations of Physicochemical Parameters of Interstitial Fluid in the Andoni Flats

\begin{tabular}{|c|c|c|c|}
\hline S.NO & Parameter & $F$ (Monthly variation) $F$ crit $=2.09$ & $F$ (Seasonal variation) $F$ crit $=10.13$ \\
\hline 1. & Temperature ${ }^{\circ} \mathrm{C}$ & 9.88 & 23.12 \\
\hline 2. & $\mathrm{pH}$ & 3.98 & 8.62 \\
\hline 3. & Salinity (ppt) & 14.77 & 10.99 \\
\hline 4. & $\begin{array}{l}\text { Dissolved } \\
\text { Oxygen (mg/l) }\end{array}$ & 1.46 & 2.29 \\
\hline
\end{tabular}

Table 2: Spatial Variations (Between Stations) of Physicochemical Parameters of Interstitial Fluid in the Andoni Flats

\begin{tabular}{|c|c|c|c|}
\hline S.NO & Parameter & $F$ (Monthly variation) $F$ crit $=2.89$ & $F$ (Seasonal variation) $F$ crit $=9.27$ \\
\hline 1. & Temperature ${ }^{\circ} \mathrm{C}$ & 3.65 & 2.26 \\
\hline 2. & $\mathrm{pH}$ & 4.08 & 4.46 \\
\hline 3. & Salinity (ppt) & 1.84 & 1.22 \\
\hline 4. & Dissolved Oxygen (mg/l) & 8.57 & 17.09 \\
\hline
\end{tabular}

$p H$ : The values of $\mathrm{pH}$ of interstitial fluid in the Andoni flats were generally stable. Values of $\mathrm{pH}$ ranged from 6.26 at station I in August to 7.76 at station IV in October. In most months of the year $\mathrm{pH}$ 
values fluctuated between 7 and 7.5 in stations I, III and IV (Fig. 3). The $\mathrm{pH}$ values recorded in station II were below seven (neutral) in most months except in February (Fig 3). ANOVA results show both spatial and temporal statistically significant differences in monthly $\mathrm{pH}$ values across stations $(\mathrm{P}<0.05)$; however the mean $\mathrm{pH}$ value for dry season though higher than that of the wet season did not vary significantly from one station to the other $(\mathrm{P}>0.05)$, (Tables 1 and 2).

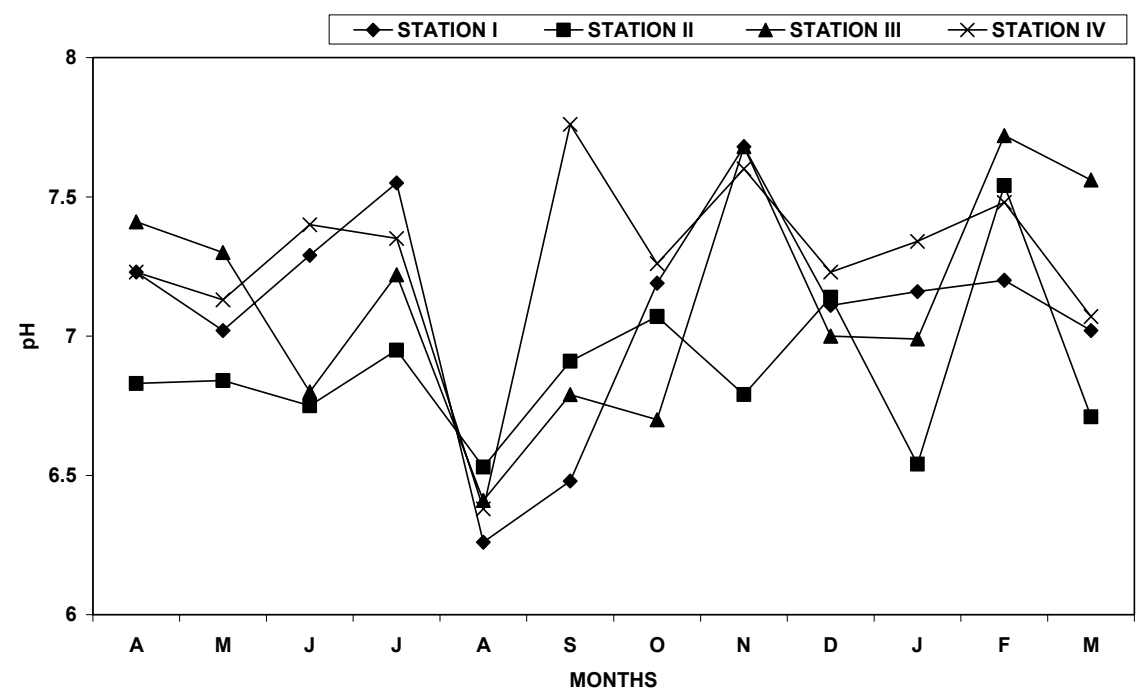

Fig. 3: MEAN MONTHLY VARIATION OF pH OF INTERSTITIAL FLUID IN THE ANDONI

FLATS

Salinity: Salinity of the interstitial water of the sediment in the Andoni flats was observed to fluctuate throughout the sampling period. Salinity varied between 8 ppt in station II in May and 21 ppt both in stations I and II in January and March (station I only), (Fig. 4). In station I, between March and May, salinity reduced steadily and began to rise again in June. A steady rise was observed up till August, at which time salinity was 20 ppt. This was followed by a drop in salinity from $15 \mathrm{ppt}$ in September to $12 \mathrm{ppt}$ in October and November respectively. Salinity began to rise again in December to 14 ppt. A similar trend was also observed in stations II, III and IV (Fig. 4) and no statistically significant differences in salinity were observed across stations $(\mathrm{P}>0.05$, Table 2$)$. However mean values of salinity and the analysis of variance tables showed that salinity values obtained in the dry season were significantly higher than in the wet season $(\mathrm{P}<0.05$, Table 1$)$.

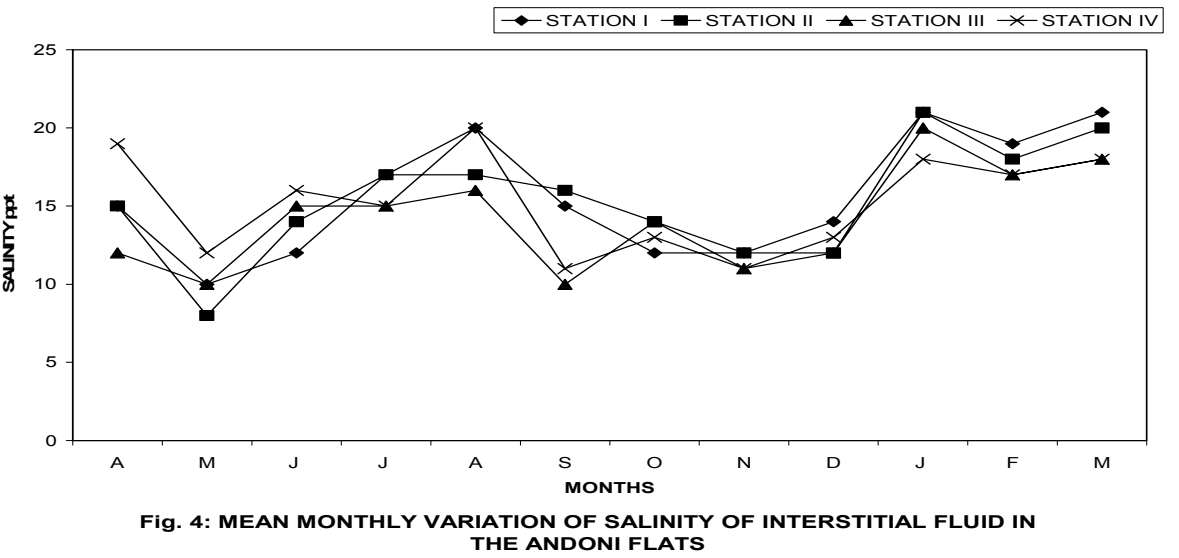

Dissolved Oxygen: Dissolved oxygen values in sediment interstitial fluid varied between 0.1 in December at station II and $1.3 \mathrm{mg} / 1$ in November at station I (Fig 5). Statistically significant spatial variations were observed in concentrations of dissolved oxygen $(\mathrm{P}<0.05$, Table 2$)$; however the reverse was the case for observed values over time $(\mathrm{P}>0.05$, Table 1$)$. 


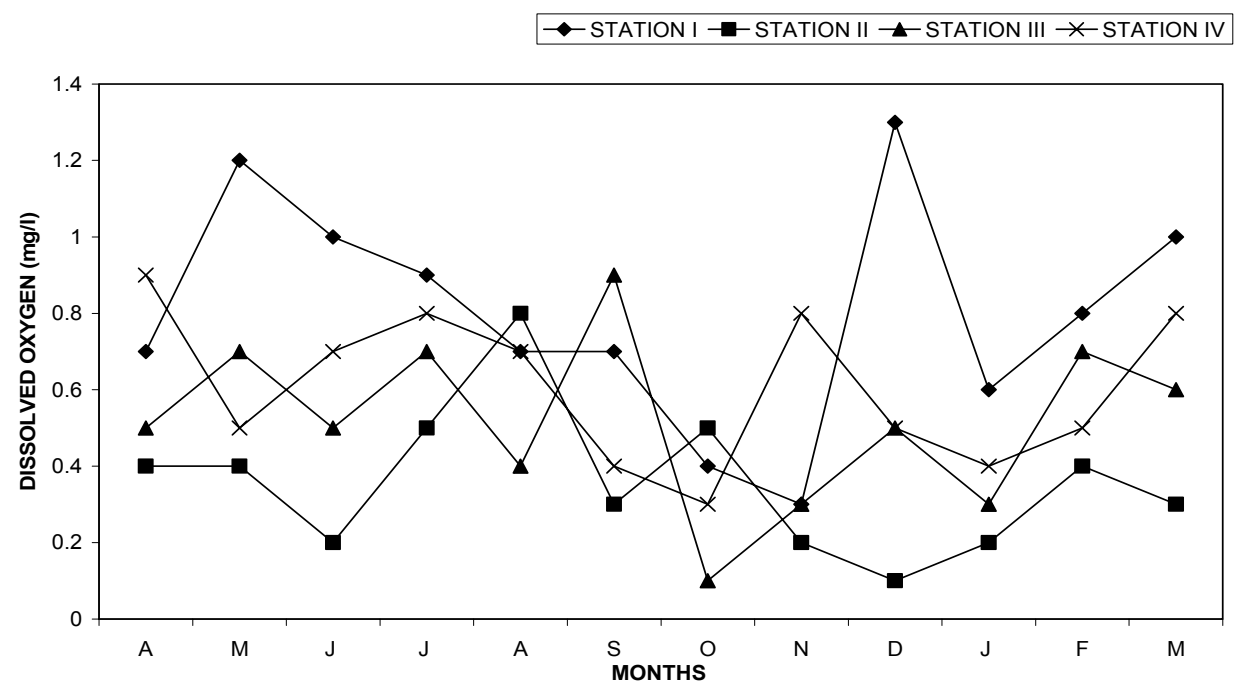

Fig. 5: MEAN MONTHLY VARIATION OF DISSOLVED OXYGEN (mg/l) IN INTERSTITIAL FLUID IN THE ANDONI FLATS

\section{DISCUSSION}

Physicochemistry of Interstitial Fluid

Temperature: Spatial differences were observed for temperature across stations. The highest values of temperature were recorded in stations I and III; indicating that these two stations heat up faster than stations II and IV due to longer hours of insolation at low tide. Station II covered to a large extent by red mangrove vegetation which provided shade over the sediment and thus resulted in a cooling effect; while station IV was in the subtidal zone and was always submerged by the river water which may be slow in transmitting the convection currents of heat from the sun when compared to the air. However a temperature range of $25.9^{\circ} \mathrm{C}$ to $32.4^{0} \mathrm{C}$ indicated a hot environment. Temporal variations in temperature observed for the Andoni flats indicated that temperature values were significantly higher in the dry season than in the wet season $(\mathrm{P}<<0.05$, Table 1). A similar trend was reported in the New Calabar River (Ekeh and Sikoki, 2003) and in the Lagos Lagoon where lowest temperature of $25^{\circ} \mathrm{C}$ was recorded in the wet season and high temperatures ranging from $28-32^{\circ} \mathrm{C}$ were recorded in the dry season (Ajao and Fagade, 2002).

Hydrogen ion concentration $(\mathrm{pH})$ : The values of $\mathrm{pH}$ of the interstitial fluid of sediments in stations I, III and IV were generally close to neutral (7) (Fig. 3). pH values in station II fell below seven in most months of the year indicating that the fluids in this station tend towards acidity. A higher mean $\mathrm{pH}$ value for the dry season than that of the wet season in the Andoni flats, could be attributed to the influx and decay of debris and leaf litter from mangrove trees in the area. A similar trend was reported by Dublin-Green (1992) in the Bonny River, where the highest $\mathrm{pH}$ values were recorded in the dry season and lower values of $\mathrm{pH}$ recorded in the late rainy season. Low $\mathrm{pH}$ value in the month of July (wet season) was also reported in the New Calabar River (Ekeh and Sikoki, 2003). The high density of leaf litter and the subsequent decay of mangrove roots and leaves in the Andoni flats could have contributed to the slightly acidic nature of the interstitial fluid in station II.

Salinity: A temporal pattern of variation for salinity was observed in the Andoni flats. The highest salinity values were recorded in the dry season from November to March which had correspondingly low rainfall values. Oyewo et al. (1982) reported that salinity cycle in the Lagos Harbour is directly dependent on rainfall. This was also observed in the Andoni flats where the highest salinity values were observed in the dry season and the lowest values recorded in the rainy season; at which time the water is heavily diluted by rain water and run-offs from land drainage. This indicated that salinity of the interstitial fluid of sediment was affected by rainfall. However, fluctuations in salinity were observed during the wet season from May to October with a sudden rise in salinity in August (attributed to the August break in rainfall pattern) forestalled by a sudden drop in September which correspondingly had a high amount of rainfall (Federal Ministry of Aviation, Dept of Meteorological Services; unpublished rainfall data). This is not uncommon in estuaries which are known for their fluctuating environmental variables (Venberg and Venberg, 1981).

Dissolved Oxygen: The concentration of dissolved oxygen in the interstitial fluid exhibited a spatial 
pattern. Station II recorded the lowest dissolved oxygen values; reaching $0.1 \mathrm{mg} / \mathrm{l}$ in some months; while station I recorded the highest values of dissolved oxygen in the interstitial fluids followed by stations III and IV. The observed differences could be related to the fact that station II has a higher organic matter content than the other three stations (Ansa and Francis, in press) and as such is prone to oxygen depletion due to the activities of bacteria which are normally present in high numbers in organically rich sediments (Barnes and Hughes, 1988). Furthermore, low concentration of oxygen is attributed to corresponding high temperatures. This trend was observed in the sediment interstitial fluid in the Andoni flats; where low dissolved oxygen concentrations were observed in the interstitial fluid across stations with a mean of less than $1 \mathrm{mg} / 1$. This is in contrast to values obtained for the main river system which always exceeded $5 \mathrm{mg} / 1$ (Personal observation; Francis, 2003). Similarly, Sikoki and Veen (2004) reported that the dissolved oxygen values in the Shiroro Lake varied between $2.3 \mathrm{mg} / \mathrm{l}$ in bottom water samples and $12.0 \mathrm{mg} / \mathrm{l}$ in surface water samples.

Conclusion: The environmental variables (high temperatures, low $\mathrm{pH}$, fluctuating salinity and low dissolved oxygen) of the intertidal areas of the Andoni flats are harsh, and benthic macrofauna thriving in this environment could be referred to as being hardy and stress tolerant. Data obtained from this study could be used as a point of reference in case impact on the Andoni flats which is a sensitive ecological zone in the Niger Delta region.

\section{REFERENCES}

Ajao, EA; Fagade, SO (2002). The benthic macrofauna of Lagos Lagoon. The Zoologist. Vol. 1 (2): $1-15$.

Akpan, ER (1999). Spatio-seasonal trends of physicochemical characteristics of Cross River Estuary, Nigeria. Halophyte uses in different climates I. pp 127-131.

Akpan ER, Offem, JO (1993). Seasonal variation in water quality of the Cross River, Nigeria. Rev. Hydrobiol. trop. 26 (2): 95-103.
Akpan, ER; Ekpo, HE; Ekpe, UJ (2003). Seasonal variation in water quality of the Calabar River: influence of tidal and coastal activities. Global Journal of environmental Sciences. 2(2): 106110.

Barnes, RSK; Hughes, RN (1988). An introduction to marine ecology. 2nd edition. Blackwell Scientific Publications. 351p.

Dublin - Green, CO (1992). Benthic foraminiferal ecology and sediment distribution in the Bonny River, Niger Delta. Ph.D. Thesis. University of London, 327p.

Edokpayi, CA; Lawal, MO; Okwok, NA; Ogunwenmo, CA (2004). Physicochemical and macrobenthic faunal characteristics of Kuramo Water, Lagos, Southern Nigeria. African Journal of Aquatic Science.

Ekeh, IB; Sikoki, FD (2003). The state and seasonal variability in some physicochemical parameters of the New Calabar River, Nigeria. Supp.ad Acta Hydrobiologica. 5, $45-60$.

Francis, A (2003). Studies on the ichthyofauna of the Andoni River system in the Niger Delta of Nigeria. PhD Thesis, University of Port Harcourt. 279 p.

Oyewo, EO; Ajao, EA; Orekoya, T (1982). Seasonal variations in surface temperature and salinity around Lagos harbour, Nigeria. NIOMR Tech. Pap. No. 10, 20pp

Sikoki, FD; Veen, JV (2004). Aspects of water quality and the potential for fish production of Shiroro Reservoir, Nigeria. Liv. Sys.Sus. Dev. 2, $7 \mathrm{pp}$.

Venberg, FJ; Venberg, WB (1981). Functional adaptations of marine organisms. Academic Press. Inc. New York. 347p. 